\title{
Clinical legal education: determining the mission and focus of a university law clinic and required outcomes, skills $\&$ values
}

M A (Riëtte) Du Plessis

LLM PhD

Associate Professor, School of Law, University of the Witwatersrand Johannesburg

\section{OPSOMMING}

Kliniese Regsopleiding: Die Vasstelling van die Missie en Fokus van 'n Universiteitregskliniek en die Verwagte Uitkomste, Tegnieke en Waardes

Die doel en fokus van verskillende tipes regsklinieke word aangedui waarna daar op universiteitsregsklinieke gefokus word. Kritiek vanuit die regspraktyk rakende die praktiese gereedheid van LLB graduandi bevestig die belangrike rol van praktiese regskursusse. Sodanige kursusse moet, ten einde suksesvol te wees, volgens universeel aanvaarbare riglyne beplan word. Alvorens 'n leerplan beplan word, moet die kliniek se missie en fokus, asook die rol van die kliniese toesighouers bepaal word. Die leerplan moet aan bepaalde uitkomste, tegnieke en waardes voldoen. In hierdie artikel word uitkomste, tegnieke en waardes uit verskeie internasionale jurisdiksies saamgevat en met die van Suid-Afrikaanse universiteitsregsklinieke vergelyk. Die doel is tweesydig: die resultaat toon eerstens in hoeverre Suid-Afrikaanse klinieke aan internationale tendense voldoen Tweedens verleen dit dan ook aan Suid-Afrikaanse klinieke die geleentheid om hulle leerplanne in die lig van die resultate te hersien, waar nodig.

\section{Introduction}

In South Africa two different types of law clinics can be identified. First, law clinics with their main missions and areas of focus being to serve the indigent members of the community by providing free legal services the justice centres of Legal Aid South Africa are the most prominent examples. Second, university law clinics also strive to serve the indigent members of the community, but their main focus area is providing practical training to LLB students in an academic clinical environment, whilst the free legal services are rendered. These clinical courses are referred to as clinical legal education (“CLE”).

Since the introduction of the four-year undergraduate LLB degree in 1997, legal practice complained about the level of preparation of the LLB

How to cite: Du Plessis 'Clinical legal education: determining the mission and focus of a university law clinic and required outcomes, skills $Q$ values 2015 De Jure $312-327$ 
graduates they recruit and the Law Society of South Africa has indicated that students are generally unprepared to enter practice. ${ }^{1}$ In view of this criticism, CLE provides the setting from where shortcomings can be addressed.

CLE serves a two-fold purpose, namely practical legal training of students and providing free legal services to the (indigent) community. ${ }^{2}$ The mission of a university law clinic lies at the core of the operation of such an entity. The mission will inform the focus of the university law clinic and the roles of the clinicians. Furthermore, where there is a focus on the training of students, an assessable curriculum must be in place to ensure academic sustainability of the clinical course. Before such a curriculum can be designed, finalised and implemented, the outcomes, skills and values of the clinical course should be determined. An assessable curriculum should be designed to comply with such outcomes, skills and values, all of which should conform to the mission of the university law clinic.

\section{Determining the Mission of the Clinic}

The most valuable clinical programmes prove to be those which place significant operational responsibility in the hands of students, because that level of trust encourages their learning more effectively than any other strategy. ${ }^{3}$ In South Africa, students were allowed to consult with clients within a few weeks (or often less than that) from the onset of such clinics during the early 1970 s. $^{4}$ This trend currently continues, ${ }^{5}$ and is

1 A number of law firms complained about the level of preparation of the LLB graduates they recruit, see http://www.universityworldnews.com/ article.php?story $=20140424114611428$ (accessed 2015-04-22); the CEO of Law Society South Africa also indicated that most students did not have the requisite academic literacy or numeracy skills to complete the undergraduate LLB degree in four years, see http://www.university worldnews.com/article.php?story $=20140424114611428$ (accessed 201504-22).

2 South African universities have identified their objectives as three-fold, namely teaching, community service and academic research. See Wimpey $\&$ Mahomed 'The practice of freedom - the South African experience' 2006 Unpublished, Copy on file with author 17. University law clinics generally have to satisfy two main objectives, namely teaching of the students and service to the community. See Du Plessis "Closing the gap between the needs of students and the community they serve' 2008 Journal for Juridical Science ('JJS') 33.

3 Evans \& Hyams 'Independent Valuations of Clinical Education Programs' 2008 Griffith Law Review 60

4 De Klerk et al Clinical law in SA (2006) 264.

5 At the University of Pretoria Law Clinic, students attend an intensive twoday workshop, where after they consult with clients, initially in groups, later in pairs and eventually as individuals. See Haupt 'Some aspects regarding the origin, development and present position of the University of Pretoria Law Clinic' 2006 De Jure 235. At the Law Clinics of the Universities of the Witwatersrand and Johannesburg, students consult with clients from the 
mirrored at Monash in Australia. ${ }^{6}$

In order to design clinical programmes, it is imperative that the clinic has a clear mission. In most law schools, CLE is taught in a live-client environment. Hyams, voicing an Australian perspective, indicates that a: 7

Clinic has a broader mandate than just the integration of practical legal skills with knowledge of the law. Clinicians can (and should) take on the mantle of teaching for lifelong learning, which includes three additional requirements of a professional ... - autonomy, judgment and a commitment to lifelong education

When formulating a mission statement, the clinic's primary constituencies need to be identified and, thereafter, the framework for dialogue on the mission should be established. ${ }^{8}$ Potential constituencies include the public served, students, employers of law graduates, law schools, applicants for admission, taxpayers, alumni, courts, all the role players in the legal profession and the university to which the clinic is attached. ${ }^{9}$ Some important points to consider are: ${ }^{10}$ The knowledge, skills and values a lawyer may require during the next ten to twenty years; the technology that must be mastered; whether a broad base of knowledge and a wide range of skills will suffice, or will specialisation be required; ${ }^{11}$ the emphasis on scholarship; ${ }^{12}$ how teaching, research and service should be prioritised; ${ }^{13}$ and what society's need for lawyers be in

second week of clinic duty and at the University of the Free State Law Clinic students already consult during their first clinical session.

6 Hyams 'On teaching students to "act like a lawyer": What sort of a lawyer?' 2008 International Journal of Clinical Legal Education (IJCLE) 25. Students at Monash, Australia are, within a few weeks from the start of their clinical course, trusted to see clients on their own and to provide advice to clients after consulting with the clinician. This proved to be effective in developing respect for clients, increased student confidence and the educational outcome of rapid but sustained and comprehensive student learning.

7 Hyams 2008 IJCLE 25

8 There must be collaboration between the legal profession, which regulates the post-degree vocational training phase, and the academy, which controls the foundational education phase. See Greenbaum 'Current issues in legal education: a comparative review' 2012 SALJ 26.

9 Munro 'How do we know if we are achieving our goals?: Strategies for assessing the outcome of curricular innovation' 2002 Journal of the Association of Legal Writing Directors 231; Swanepoel, Karels \& Bezuidenhout 'Integrating theory and practice in the LLB curriculum: Some reflections' 2008 JJS Special Issue 101.

10 Munro 2002 Journal of the Association of Legal Writing Directors 231-232.

11 Ibid.

12 Ibid; it is submitted that scholarship is necessary in order to theorise about the wider area of clinical legal education.

13 Ibid; it is submitted that there is uniqueness to the university law clinics in South Africa, specifically as instruments of social justice, which originated during the apartheid-era. What is important for the clinics 20 years into the South African democracy is to build on the past and assess what the current context is. The current context calls for a prioritising of teaching of students in CLE courses. 
the future (numbers, fields of specialisation or multi-disciplinary practice)? ${ }^{14}$ Fisher proposes that typical mission statements should address the preparation of students for the practice of law, ${ }^{15}$ promoting justice and scholarship, ${ }^{16}$ encouraging diverse perspectives and communities, ${ }^{17}$ including service and embracing high ethical standards. ${ }^{18}$

A recent PhD study reviewed the CLE mission statements of four South African university law clinics, namely those of the Universities of the Witwatersrand, Pretoria, Johannesburg and Free State. ${ }^{19}$ The mission statements of these university law clinics are indicated.

The mission statement of the Wits Law Clinic was formulated in 2006 and reads: "The Wits Law Clinic aspires to: develop and provide an effective clinical legal education programme to students; promote published research by clinical teachers; and to provide quality legal services to the community". ${ }^{20}$

The University of Pretoria's Law Clinic's mission statement reads. ${ }^{21}$

To use the practice of law (simulated and actual) as a context to teach and research substantive and procedural law, ethics, professional skills, effective interpersonal relations, appropriate dispute resolution techniques and the ability to integrate law, fact, procedure and values; to provide quality legal services to the indigent thereby increasing access to justice; to promote access to and transformation of the organised legal profession by providing opportunities and training to candidate attorneys especially those from previously disadvantaged groups; and to foster a commitment in staff and students to build a society based on democratic values, social justice and the rule of law.

The University of Johannesburg's Law Clinic states that the aim/ mission of their CLE course, Applied Legal Studies (incorporated into their clinic), is two-fold: Firstly, the clinical legal education of final year LLB students, with the focus on analytical skills, the application of theory and an appreciation of the practical nature and consequences of theory; and secondly, the rendering of free legal services to the indigent according to the guidelines of the Attorneys Act, ${ }^{22}$ and the Law Society of the Northern Provinces. ${ }^{23}$

14 Ibid

15 Fisher 'Putting students at the center of legal education: how an emphasis on outcome measures in the ABA standards for approval of law schools might transform the educational experience of law students' 2011 Southern Illinois University Law Journal 225.

16 Ibid

17 Ibid

18 Idem 3.

19 Du Plessis Assessment methods in clinical legal education (PhD thesis 2014 University of the Witwatersrand).

20 Mahomed 'United in our challenges - Should the model used in clinical legal education be reviewed?' 2008 JJS 63.

21 University of Pretoria Law Clinic, Practical Law 410 study guide (2012) 3.

22 Act 53 of 1979. 
The mission and vision of the University of the Free State Law Clinic is stated as a venture conducted by the University's Faculty of Law, where primarily: a) members of the indigent society of the greater Mangaung area of the Free State Province, that qualify in terms of a means test, receive free legal services; and b) that final year students of the Faculty receive practical legal training, are exposed to various aspects of legal practice and engage in community service learning projects. ${ }^{24}$

Once a clinic's mission is determined, it will be the foundation from which the subsequent student and institutional outcomes, curriculum, teaching methods and assessment will be reflected. ${ }^{25}$

\section{The Focus of the Clinic, CLE and the Role of the Clinician}

The focus of a university's law clinic, which forms part of the university's law school and generally includes an accredited academic course in the law degree curriculum, is key in determining how the teaching methodology of CLE will be applied in the training of the students and the setting of the curriculum. This, in turn, will determine the role of the clinician, who fulfils a dual role, namely that of an attorney/lawyer assuming professional responsibility for all the matters that the students are dealing with - and that of a law teacher who has to account to the university as his/her employer.

South African universities state their objectives as threefold, namely teaching, community engagement and academic research. ${ }^{26}$ University law clinics comply with the first two objectives. Academic research by law clinic clinicians, resulting in accredited publication output, is already an essential objective of some law clinics. ${ }^{27}$ During the 2011 Association of University Legal Aid Institutions ("AULAI"; now "SAULCA") winter conference, ${ }^{28}$ it was confirmed by the delegates that such research output should form an essential objective for all South African law clinics. $^{29}$

Although tension exists between the teaching of students and client services, ${ }^{30}$ the general view across a number of jurisdictions is that the

23 University of Johannesburg, Applied Legal Studies learning guide (2012) 2.

24 University of the Free State Law Clinic: 'Mission and Vision', available at the University of the Free State Law Clinic.

25 Munro 2002 Journal of the Association of Legal Writing Directors 231-232.

26 Wimpey \& Mahomed supra n 2 at 17.

27 Du Plessis 'Access to justice outside the conventional mould: creating a model for alternative clinical legal training' 2007 JJS 46.

28 Note that at a Special General Meeting held in Port Elizabeth at the Nelson Mandela Metropolitan University on 5 July 2013, the name 'AULAI' was changed to 'SAULCA - South African University Law Clinics Association'.

29 The conference was held from 27-30 June 2011 and was hosted by the University of the Western Cape. 
main focus of a university law clinic should be CLE - that is, the teaching of students by the clinicians and not the provision of free legal services. ${ }^{3}$

The South African view, as was confirmed by the delegates during the 2011 AULAI winter conference, was set out by Du Plessis as follows: ${ }^{32}$

Where clinical legal education is compulsory, the role of law clinics in the academic environment becomes more pronounced and a stronger emphasis is placed on the academic training of students in the clinical environment. Access to justice for the indigent is no longer the main or only focus of the law clinic, but will remain a strong component, as client service is inseparable from the clinical methodology.

De Klerk echoed this view, stating that: ${ }^{33}$

Students pay good money to complete clinical courses and have legitimate expectations of the benefits they should receive in return. The teaching that takes place in a clinic should therefore never be incidental or secondary to the practice of law. Teaching students remains the core business of (university) law clinics.

The Clinical Legal Education Organization ("CLEO") in the United Kingdom ("UK”) holds the view that: 34

$[\mathrm{H}]$ owever much the clinic wishes to advise and assist those members of the community who have unmet legal needs ... the principal aim of clinical programmes is educational. It is the needs of the student and supervisor competence that must dictate which clients are assisted and in what areas.

\section{For South Africa, Du Plessis states that: ${ }^{35}$}

In planning the clinical curriculum, clinicians have to define the parameters within which the clinic should operate. Only types of cases that will satisfy the goals of clinical legal education should be considered, and [clinicians] should limit the volume of cases taken on ... to ensure that students derive the best possible training ...

30 Stuckey et al Best practices for legal education (2007) 197; Giddings 'Contemplating the future of clinical legal education' 2008 Griffith Law Review 7.

31 See Du Plessis \& Dass 'Defining the role of the university law clinician' 2013 SALJ 390-406 for a full discussion on defining the role of the university law clinician.

32 Du Plessis 2007 JJS 46.

33 De Klerk 'Unity in Adversity: Reflections on the Clinical Movement in South Africa' 2007 IJCLE 98. This was also confirmed in De Klerk \& Mahomed 'Specialisation at a University Law Clinic: The Wits Experience' 2006 De Jure 31; and by Haupt supra $\mathrm{n} 5$ at 237.

34 CLEO 'Model standards for live-client clinics' 2007 A Clinical Legal Education Organization ('CLEO') document http://www.ukcle.ac.uk/resour ces/teaching-and-learning-practices/clinical-legal-education/ (accessed 201106-14); MacFarlane \& McKeown '10 lessons for new clinicians' 2008 IJCLE 65

35 Du Plessis 2008 JJS 14 
In both the United States of America ("USA") and the UK, CLE is about the student experience and it should, therefore, be the student who conducts a case, not the clinician. ${ }^{36}$ If students are only told what to do, they do not learn much - they must learn why certain practices are better and learn necessary lawyerly skills and relationships with clients, adversaries and adjudicators. Therefore, the case file belongs to the student, as a teaching tool, and the student must do the work, not observe it being done. The clinician should, therefore, not practice but train the student to practice. ${ }^{37}$

\section{Outcomes, Skills and Values}

Outcomes, skills and values are foundational to the design of a CLE curriculum. In the USA, Canada and Australia "accreditation has been used to drive legal education toward an outcomes-based learning model in which knowledge, skills and values must be clearly articulated and tangibly demonstrated." 38

Expected outcomes, skills and values were identified as preconditions in designing a curriculum that can be assessed effectively. As the course relates to the training of legal professionals, it is important to identify the skills, values and outcomes that are required by the profession. The following were identified across a number of jurisdictions. ${ }^{39}$

36 MacFarlane \& McKeown 2008 IJCLE 65; Wizner 'Beyond skills training' 2001-2002 Clinical Law Review ('CLR') 13; Stuckey supra n 30 at 195-197.

37 'Practice' in this context refers to the total of the practice concerning the specific case, excluding the court appearance. The student should ideally, with the supervision of the clinician, prepare a case from the initial consultation until the case is ready to go to trial.

38 Smyth \& Liddle 'Lulling ourselves into a false sense of competence: learning outcomes and clinical legal education in Canada, the United States and Australia’ 2012 Canadian Legal Education Annual Review 21.

39 Identified and proposed by the Law Society of England and Wales, see Stuckey supra n 30 at 44; for the State Bar of Wisconsin's Commission on Legal Education, see Findley 'Rediscovering the lawyer school: curriculum reform in Wisconsin' 2006-2007 Wisconsin International Law Journal 324; for the USA and Canada see 'Section on legal education and admissions to the bar, American Bar Association's legal education and professional development - an educational continuum, report of the task force on law schools and the profession: narrowing the gap' 1992 (the 'MacCrate Report') available from http://www.abanet.org/legaled/publications/ onlinepubs/maccrate.html\#B) (accessed 2011-06-14); for the Bar Council of India see Bloch \& Prasad 'Institutionalizing a social justice mission for clinical legal education: cross-national currents from India and the United States' 2006 CLR 209-212; for Australia see Giddings 2008 Griffith Law Review 12; for Germany see Brücker \& Woodruff 'The Bologna Process and German Legal Education: Developing Professional Competence through Clinical Experiences' 2008 German Law Journal 579. 


\section{Outcomes}

Outcomes were defined as "the stated abilities, knowledge base, skills, personal attributes, and perspectives on the role of law and lawyers in society". 40 The outcomes of a clinical programme are relevant to the needs of the society, students and the profession. ${ }^{41}$ In July 2008, the American Bar Association ("ABA") shifted its focus from input measures to outcomes assessment, thereby urging law teachers to develop clear learning outcomes for their courses. ${ }^{42}$

When planning a curriculum, certain outcomes are expected. In South Africa, seven main goals (outcomes), each with their own sub-goals, of CLE have been identified. ${ }^{43}$ Goal one relates to professional responsibility. The sub-goals (outcomes) are: A system of legal ethics and ethical philosophy; personal norms/morality; the professional role of legal practitioners; the analysis of legal institutions; social awareness; and affording students the opportunity to reform the system. Goal two is judgment and analytical abilities. The sub-goals (outcomes) are: Recognition of relevant facts and applicable law; understanding strategy, tactics and decision making; understanding process and procedure; synthesis; and reflection. Goal three is the knowledge of substantive law. The sub-goals (outcomes) are: Strengthening and deepening of existing knowledge; acquiring new knowledge; the impact of theory (strengthening and extending acquired theory); and the study of specific law areas. Goal four relates to applied practice skills. The sub-goals (outcomes) are: Consultation skills; client counselling; negotiation; trial advocacy; appellate advocacy; drafting of legal documents; legal research; factual investigation; and office management. Goal five is rendering legal services to the community, which ties in with goal six where students are required to learn and work in groups. Goal seven is the integration of all or some of these goals.

\section{Outcomes Summary}

A summary of the abovementioned jurisdictions' identified outcomes indicate that when outcomes for CLE are determined, the following should be considered: The outcomes stated by the abovementioned

40 Munro 2002 Journal of the Association of Legal Writing Directors 232.

41 Osman 'Meeting quality requirements: a qualitative review of the clinical law module at the Howard College Campus' 2006 De Jure 275.

42 Carpenter et al 'American Bar Association, Report of the Outcome Measures Committee' 3 http://www.abanet.org/legaled/committees/subcomm/Out come \% 20Measures \% C20Final\% 20Report.pdf (accessed 2013-08-01); Hill 'Peer Editing: a comprehensive pedagogical approach to maximize assessment opportunities, integrate collaborative learning, and achieve desired outcomes' 2011 Nevada Law Journal 668.

43 De Klerk et al supra $\mathrm{n} 4$ at 266-279. 
multiple jurisdictions, ${ }^{44}$ indicated below, and that of the seven main goals (outcomes), each with their own sub-goals, identified for South Africa were compared. Seventeen outcomes were identified by the multiple jurisdictions. The results are as follows:

(a) Collaboration with legal practice:

The outcomes identified, according to the seven main goals, for South Africa ('SA outcomes') are: Professional responsibility and legal ethics, in line with goal one.

(b) The professional role of legal practitioners:

SA outcomes: Analysis of legal institutions (goal one).

(c) Consistent with the mission of the school and the university:

SA outcomes: Mission statements of the four South African universities reviewed are consistent.

(d) Assessable:

SA outcomes: The outcomes stated by the four South African universities reviewed are assessable.

(e) Must be stated:

SA outcomes: The outcomes were stated by the four South African universities that were reviewed.

(f) Substantive law:

SA outcomes: Substantive law (goal three)

(g) Procedural law:

SA outcomes: Judgment and analytical abilities, understanding, process and procedure, and synthesis (goal two).

(h) Professional conduct:

SA outcomes: Professional responsibility, legal ethics, the professional role of legal practitioners and the analysis of legal institutions (goal one).

(i) Client care:

SA outcomes: Social awareness and legal services to the community (goals one and five).

(j) Ethics:

SA outcomes: Legal ethics (goal one).

(k) Conduct and initial interview:

SA outcomes: Applied practice skills, consultation skills, judgment and analytical abilities, recognition of relevant facts and applicable law, understanding strategy, tactics and decision making (goals two and four).

(l) Preliminary written advice:

SA outcomes: Applied practice skills, judgment and analytical abilities, recognition of relevant facts and applicable law, understanding, strategy, tactics and decision making (goals two and four).

(m) Appropriate English and the ability to draft letters:

44 Identified and proposed by the Law Society of England and Wales, see Stuckey supra $\mathrm{n} 30$ at 44; the State Bar of Wisconsin's Commission on Legal Education, see Findley supra $n 39$ at 324; for the USA and Canada see the MacCrate Report supra $n$ 39; for the Bar Council of India see Bloch \& Prasad supra n 39 at 209-212; for Australia see Giddings supra n 39 at 12; for Germany see Brücker \& Woodruff supra n 39 at 579. 
SA outcomes: Applied practice skills (goal four).

(n) Draft formal documents:

SA outcomes: Applied practice skills and the drafting of legal documents (goal four).

(o) The ability to bring a case to an appropriate resolution:

SA outcomes: Applied practice skills, counselling, negotiation, trial and appellate advocacy, legal research, factual investigation, judgment and analytical abilities, recognition of relevant facts and applicable law, understanding strategy, tactics and decision making (goals two and four).

(p) To work effectively in a group:

SA outcomes: Learning and working in groups (goal six).

(q) The capacity to reflect on his/her learning and performance:

SA outcomes: Reflection and office management (goals two and four).

\section{Skills}

The Queensland University of Technology, encouraged by the Australian Law Reform Commission's 2000 exhortation to re-orientate legal education around "what lawyers need to be able to do", propose the following set of skills. 45

Table of Skills by Category:

$\begin{array}{llll}\text { Attitudinal skills } & \text { Cognitive skills } & \begin{array}{l}\text { Communication } \\ \text { skills }\end{array} & \text { Relational skills } \\ \text { Ethical orientation } & \text { Problem solving } & \text { Oral } & \text { Work } \\ \text { Creative outlook } & \text { Legal analysis } & \text { communication } & \text { independently } \\ \text { Reflective practice } & \text { IT literacy } & \text { Oral presentations } & \text { Teamwork } \\ \text { Inclusive } & \text { Legal research } & \text { Advocacy } & \text { Appreciate race, } \\ \text { perspective } & \text { Document } & \text { Legal interviewing } & \text { gender, culture } \\ \text { Social justice } & \text { management } & \text { Mooting } & \text { and socio- } \\ \text { orientation } & \text { Discipline } \& \text { ethical } & \text { Negotiation } & \text { economic } \\ \text { Adaptive } & \text { knowledge } & \text { Written } & \text { differences } \\ \text { behaviour } & & \text { communication } & \text { specifically and } \\ \text { Pro-active } & & \text { Drafting } & \text { diversity generally } \\ \text { behaviour } & & & \text { Time management } \\ & & & \end{array}$

In summarising research done across a wide jurisdiction, the following skills were identified as essential skills that law graduates should have, or would need to have, when entering the legal profession: ${ }^{46}$ Ethics; practice management; case management; interviewing skills; the

45 Kift 'A tale of two sectors: dynamic curriculum change for a dynamically changing profession' 13 th Commonwealth Law Conference: Developing the Law Curriculum to Meet the Needs of the $21^{\text {st }}$ Century Legal Practitioner (Melbourne, Australia) 13-17 April 2003. Conference paper unpublished 113 abstract available from http://eprints.qut.edu.au/7468/.

46 Identified and proposed by the Law Society of England and Wales, see Stuckey supra n 30 at 44; the State Bar of Wisconsin's Commission on Legal Education, see Findley supra $n 39$ at 324; for the USA and Canada see the MacCrate Report supra $n$ 39; for the Bar Council of India see Bloch \& Prasad supra n 39 at 209-212; for Australia see Giddings supra n 39 at 12; for Germany see Brücker \& Woodruff supra n 39 at 579. 
capacity to deal sensitively and effectively with clients, colleagues and others from a range of social, economic and ethnic backgrounds and disabilities; effective communication techniques; recognition of clients' financial, commercial and personal constraints and priorities; effective problem-solving; the ability to use current technologies; legal research; time management and billing; risk management; recognising personal strengths and weaknesses and developing strategies to enhance personal performance; managing personal workload and the number of client matters (clinicians must set the example - if you are a teacher, then limit client intake to teach efficiently); working as part of a team (pairing of students or doing certain activities in a group, in the clinic, are invaluable); legal analysis and reasoning; factual investigation; counselling (to establish a counselling relationship with a client); negotiation; and the skills applicable to litigation and alternative dispute resolution procedure, i.e. trial advocacy.

In South Africa, the skills taught comprise: ${ }^{47}$ Professional and ethical conduct. The teaching of this skill will include the rules of professional ethics; ${ }^{48}$ what the term "legal practitioner" entails; what constitutes a fit and proper person to be admitted as a legal practitioner; misconduct; professional negligence; the sources where the rules of professional conduct originate from; practitioners' relationship with the State; political dissent; criminal conduct; assisting clients in breaking the law; practitioners' relationship with the court; practitioners' relationship with clients; practitioners' relationship with the opposition and other practitioners; the relationship between attorneys and advocates; and duties towards the poor - access to justice and rules of etiquette. ${ }^{49}$

Consultation skills: The teaching of this skill will include aims of the consultation; preparing for the consultation; stages in the consultation; after the consultation; utilising checklists or client instruction sheets; and assessing consultation skills. ${ }^{50}$

File and case management: The teaching of this skill will include file management systems; opening case files; typical file structure; case management and the closing of files. ${ }^{51}$

47 De Klerk et al supra n 4 at 29-262. This textbook is the only one on CLE written by South African clinicians and is used in the majority of South African university law clinics. The authors describe the skills taught together with instruction on the teaching of the different skills. These skills are mostly taught as part of the LLB curriculum, with instructions aimed at teaching these skills as part of CLE courses.

48 For a clinical model as a vehicle for teaching ethics to law students see Kerrigan " "How do you feel about this client?" A commentary on the clinical model as a vehicle for teaching ethics to law students' 2007 IJCLE 7-26.

49 De Klerk et al supra $\mathrm{n} 4$ at 29-54. Also see Swanepoel, Karels \& Bezuidenhout 2008 JJS Special Issue 104 on the development of this skill.

50 De Klerk et al supra $\mathrm{n} 4$ at 55-71.

51 Idem 73-82. 
Numeracy skills: The teaching will include use of a calculator; basic numerical writing and reading; addition; subtraction; multiplication; division; averages; exponents; fractions; reading decimal fractions; percentages; conversions; interest; ratios and rates; apportionment of damages; calculating Value Added Tax; and combining calculations. ${ }^{52}$

Practice management: The teaching of this skill will include legal practice and professional ethics; client care and marketing; financial management; trust account management; risk management; personal management; miscellaneous statutory provisions; starting off in a practice; and the business plan. ${ }^{53}$

Legal research: The teaching will include legal research in a law clinic; suggested research methods; and the drafting of an opinion. ${ }^{54}$

Drafting letters: The teaching of this skill will include format; body of the letter; specific letters; and methods of delivery. ${ }^{55}$

Drafting pleadings, notices and applications: This will include important terms and concepts; a general approach to drafting; prior considerations; drafting of pleadings; drafting of motions/applications; and drafting of heads of argument. ${ }^{56}$

The drafting of wills: This will include general approach to drafting; prior considerations; interviewing checklist; contents and order of a will and formalities. ${ }^{57}$

The drafting of contracts: The students will be taught on the law of contract; the art of drafting; and exercises in examples. ${ }^{58}$

Alternative dispute resolution: The teaching of this skill will include types of dispute resolution processes; negotiation; mediation; and arbitration. ${ }^{59}$

Lastly, trial advocacy: The teaching of this skill will include the opening address; examination in chief cross-examination; limitations on crossexamination; technique in cross-examination; re-examination; and the closing address. This will also include practical exercises. ${ }^{60}$ 


\section{Skills Summary}

The skills identified across a number of jurisdictions and those identified for South Africa were also compared. 22 skills were identified across a number of jurisdictions. ${ }^{61}$ The results are as follows:

\section{(a) Ethics:}

Skills taught in South Africa ('SA skills'): Professional and ethical conduct, ${ }^{62}$ and professional responsibility. ${ }^{63}$

(b) Practice management:

SA skills: Practice management, ${ }^{64}$ financial management, ${ }^{65}$ and office administration. 66

(c) Case management:

SA skills: File and case management. ${ }^{67}$

(d) Interviewing skills:

SA skills: Consultation skills. ${ }^{68}$

(e) The capacity to deal sensitively and effectively with clients, colleagues and other from a range of social, economic and ethnic backgrounds and disabilities:

SA skills: Social justice, ${ }^{69}$ welfare, ${ }^{70}$ HIV/AIDS. ${ }^{71}$

(f) Effective communication techniques:

SA skills: Consultation skills, ${ }^{72}$ analysis of facts and law. ${ }^{73}$

(g) Recognise clients' financial, commercial and personal constraints and priorities:

SA skills: Social justice, ${ }^{74}$ welfare, ${ }^{75}$ HIV/AIDS. ${ }^{76}$ These are mainly taught during tutorial sessions and may also relate largely to the focus of the clinic and the clinician.

61 Identified and proposed by the Law Society of England and Wales, see Stuckey supra n 30 at 44; the State Bar of Wisconsin's Commission on Legal Education, see Findley supra $n 39$ at 324; for the USA and Canada see the MacCrate Report supra $n$ 39; for the Bar Council of India see Bloch \& Prasad supra n 39 at 209-212; for Australia see Giddings supra n 39 at 12; for Germany see Brücker \& Woodruff supra n 39 at 579.

62 De Klerk et al supra n 4 at 29-54; Swanepoel, Karels \& Bezuidenhout 2008 JJS Special Issue 104.

63 During 2005, AULAI compiled a manual with suggested topics relevant to the setting of a CLE curriculum, see Vawda (ed) AULAI Manual, Volumes 1 \& 2 (2005). See also Du Plessis (PhD thesis 2014) supra $n 19$ at 56-59. For purposes of reference to this manual, the relevant pages of the manual will be indicated under 'AULAI Manual'.

64 De Klerk et al supra $n 4$ at 103-128; AULAI Manual (2005) 32-33.

65 AULAI Manual (2005) 34-35.

66 Idem 36-39.

67 De Klerk et al supra n 4 at 73-82; AULAI Manual (2005) 32-33.

68 De Klerk et al supra $\mathrm{n} 4$ at 55-72.

69 AULAI Manual (2005) 15-31.

70 Idem 81-82.

71 Idem 75-77.

72 De Klerk et al supra $\mathrm{n} 4$ at 55-72.

73 AULAI Manual (2005) 40-45.

74 Idem 15-31.

75 Idem 81-82.

76 Idem 75-77. 
(h) Effective problem-solving:

SA skills: Consultation and analysis of facts and law, ${ }^{77}$ legal research. ${ }^{78}$

(i) To be able to use current technologies:

SA skills: These skills are not taught.

(j) Legal research:

SA skills: Legal research. ${ }^{79}$

(k) Time management and billing:

SA skills: File and case management, ${ }^{80}$ practice management, ${ }^{81}$ financial management, ${ }^{82}$ office administration. ${ }^{83}$

(l) To recognise personal strengths and weaknesses:

SA skills: These are mainly taught during tutorials.

(m) To manage risk:

SA skills: Practice management, ${ }^{84}$ file and case management, ${ }^{85}$ financial management, ${ }^{86}$ and office administration. ${ }^{87}$

(n) To develop strategies to enhance personal performance:

SA skills: These are mainly taught during tutorial sessions and may also relate largely to the focus of the clinic and the clinician.

(o) Manage personal workload and the number of client matters:

SA skills: These are mainly taught during tutorial sessions and may also relate largely to the focus of the clinic and the clinician.

(p) Work as part of a team:

SA skills: Pairing of students, working in student law firms and trial advocacy.

(q) Problem solving:

SA skills: Legal research, ${ }^{88}$ alternative dispute resolution. ${ }^{89}$

(r) Legal analysis and reasoning:

SA skills: Consultation and analysis of facts and law, ${ }^{90}$ legal research. ${ }^{91}$

(s) Factual investigation:

SA skills: These can be taught effectively in matters such as medical malpractice, ${ }^{92}$ environmental law, ${ }^{93}$ family law $^{94}$ and motor vehicle accidents. ${ }^{95}$

77 Idem 40-45.

78 De Klerk et al supra $\mathrm{n} 4$ at 129-154.

79 Ibid.

80 AULAI Manual (2005) 32-33.

81 De Klerk et al supra $\mathrm{n} 4$ at 103-128.

82 AULAI (2005) 34-35.

83 Idem 36-39.

84 De Klerk et al supra n 4 at 103-128.

85 AULAI Manual (2005) 32-33.

86 Idem 34-35.

87 Idem 36-39.

88 De Klerk et al supra $n 4$ at 129-154.

89 Idem 253-262; AULAI Manual (2005) 83-86.

90 AULAI Manual (2005) 40-45.

91 De Klerk et al supra n 4 at 129-154.

92 AULAI (2005) 78-79.

93 Idem 80.

94 Idem 87-106.

95 Idem 73-74. 
(t) Counselling:

SA skills: Consultation and analysis of facts and law ${ }^{96}$ and in matters mentioned under 'factual investigation'.

(u) Alternative dispute resolution and trial advocacy:

SA skills: Alternative dispute resolution, ${ }^{97}$ trial advocacy, ${ }^{98}$ and preparation for trial. ${ }^{99}$

(v) Negotiation:

SA skills: Alternative dispute resolution, ${ }^{100}$ and in most litigation matters.

In South Africa, the following additional skills are taught: ${ }^{101}$ Numeracy skills, ${ }^{102}$ drafting letters, ${ }^{103}$ drafting pleadings, notices and applications, ${ }^{104}$ drafting wills, ${ }^{105}$ drafting contracts. ${ }^{106}$

\section{Values}

The Carnegie Model of legal education supports courses and curricula that integrate three sets of values or "apprenticeships": Knowledge, practice and professionalism. ${ }^{107}$

Chavkin is of the opinion that there are at least three types of values which are critical to the future of the profession. ${ }^{108}$ The first is a private value, namely the lawyer-client relationship. The second and third are public values, namely the lawyer's relationship with opposing counsel, judges and court administration; and the lawyer's relationship to the profession.

In summarising research done across a wide jurisdiction, the following were identified as core values that every competent lawyer must embrace: The provision of competent representation; striving to promote justice, fairness and morality; striving to improve the profession;

96 Idem 40-45

97 De Klerk et al supra $\mathrm{n} 4$ at 253-262; AULAI Manual (2005) 83-86.

98 De Klerk et al supra n 4 at 233-252; AULAI Manual (2005) 68-70.

99 AULAI Manual (2005) 64-67.

100 De Klerk et al supra 4 at 253-262; AULAI Manual (2005) 83-86.

101 De Klerk et al supra $\mathrm{n} 4$ at 29-262.

102 Idem 83-102.

103 Idem 155-172; AULAI Manual (2005) 46-50.

104 De Klerk et al supra n 4 at 173-192; AULAI Manual (2005) 51-55.

105 De Klerk et al supra $\mathrm{n} 4$ at 193-218.

106 Idem 219-232; AULAI Manual (2005) 125-130.

107 http://educatingtomorrowslawyers.du.edu/about-etl/carnegierecommendations/ (accessed on 2015-04-22). In 1992 the MacCrate Report identified and published four values as provision of competent representation namely, striving to promote justice, fairness and morality, and striving to improve the profession and professional self-development. MacCrate Report supra n 39; see also Brücker \& Woodruff 2008 supra note 39 at 593.

108 Chavkin 'Experience is the only teacher: Meeting the challenge of the Carnegie Foundation Report' 2007 Legal Education Digest 5. 
professional and self-development; judgment; professionalism; civility; and conservation of the resources of the justice system. ${ }^{109}$

\section{Values Summary}

The core values that were identified in foreign jurisdictions are equally important and embraced in the South African landscape and are specifically evident in the teaching and practice of ethics, professionalism and case and file management.

\section{Conclusion}

It was indicated that, although university law clinics strive to serve the indigent members of the community, their main focus area is providing practical training to LLB students, in an academic clinical environment, whilst free legal services are rendered.

The mission of a university law clinic informs the roles of its clinicians and its focus, which should be on the training of students, thereby requiring an assessable CLE curriculum to ensure academic integrity and sustainability. It was indicated that an assessable curriculum must comply with the university law clinic's determined outcomes, skills and values.

Required and recommended outcomes, skills and values were identified across a number of jurisdictions and compared to those applied in the South African clinical environment. These should form the basis from which an assessable CLE curriculum can be designed. Adherence should address the complaints and criticisms by legal practice.

109 Identified and proposed by the Law Society of England and Wales, see Stuckey supra n 30 at 44; the State Bar of Wisconsin's Commission on Legal Education, see Findley supra $n 39$ at 324; for the USA and Canada see the MacCrate Report supra n 39; for the Bar Council of India see Bloch \& Prasad supra $n 39$ at 209-212; for Australia see Giddings supra n 39 at 12; for Germany see Brücker \& Woodruff supra n 39 at 579. 